\title{
Prosperity Gospel and Its Religious Impact on Sustainable Economic Development of African Nations
}

\author{
Josephine Olatomi Soboyejo \\ Crowther Graduate Theological Seminary, Abeokuta, Nigeria \\ Email: joesoboyejo@hotmail.com, joesoboyejo@gmail.com
}

How to cite this paper: Soboyejo, J.O. (2016) Prosperity Gospel and Its Religious Impact on Sustainable Economic Development of African Nations. Open Access Library Journal, 3: e3153.

http://dx.doi.org/10.4236/oalib.1103153

Received: October 17, 2016

Accepted: November 8, 2016

Published: November 11, 2016

Copyright $\odot 2016$ by author and Open Access Library Inc.

This work is licensed under the Creative Commons Attribution International License (CC BY 4.0).

http://creativecommons.org/licenses/by/4.0/

\section{(c) (i) Open Access}

\section{Abstract}

Before the advent of African priests, expatriate missionaries in Africa were noted for their detached and abstemious ways of life. They upheld what is known as "Vow of Poverty", which was taken prior to sacerdotal ordination. They toiled selflessly for their flock without caring for personal material benefits. This orientation has been discarded for prosperity vocation in this 21 st century. Priests now use luxurious cars, fly expensive private jets and are escorted by well-armed military/police officers. The social-economy context of prosperity theology has become a great attraction to impoverished people of Africa. The micro and macro economies retrogression in many African nations enable some charismatic and neo-Pentecostal preachers to incorporate prosperity messages into sermons. The doctrine emphasizes the importance of personal empowerment, proposing that it is God's will for the people to obtain wealth, health and total success in the world. This paper explains the reasons prosperity preaching is hurting Africa; and examines the capitalistic tendencies that have replaced spiritual growth and moral sanctity towards an eternal life. The paper catalogues the religious impact of prosperity gospel on sustainable economic development of African nations. Africa has many Churches; growing rapidly yet remains the only region that poverty has increased in the past two decades. So there is no impact of the prosperity message on the people. Most Africans live on less than $\$ 1$ a day and many proactive youths are still unemployed. This paper explains how people have been financially exploited, which has led to loss of "Faith" and lack of personal economic security.

\section{Subject Areas}

Philosophy 


\section{Keywords}

Prosperity Gospel/Theology, Religious Impact, Sustainable Economic Growth, and Africa Nations

\section{Introduction}

Prosperity Gospel has developed "Prosperity Theology" that berths "Cultic theology". Prosperity preachers achieve their aim through donations of money from the people, visualization, and positive confession with power-driven sermons towards personal empowerment jettisoning the Salvation message. There are four critical areas of error relating to Prosperity gospel on wealth that are examined in this paper. The attitude of early missionaries was attributed to the "vow of poverty". The said praiseworthy historic vow formed the object of a remark by Richard James Foster, a Christian theologian in his published book in 1985:

The monastic response to money is seen in the ancient vow of poverty. Intense renunciation was their way of shouting no to the prevailing values of their society. They were, however, giving far more than a negative word. They were saying no in order to say yes. They renounced possessions in order to learn detachment [1].

According to Foster, religious vows are sacred promises that reflect a life orientation and profound loving commitment. By the early missionaries' vow of poverty, they committed to share their resources, time, and talents within their communities and with those in need. Today, this orientation has been discarded for prosperity vocation with the priests living flamboyant lives. Africa is one of the seven continents of the world and has the largest number of the "Negroid"/black.

African perspective is complex and varies to a certain degree from the general views of other ethnic-groups. Their beliefs in God, Gods, god, and gods are intertwined with African traditions and culture; that makes it easy for them to be hoodwinked by the prosperity preachers. The reality of the global recession has its adverse impact on the international price of oil of oil-producing countries in Africa like Nigeria, which has led to economic recession. Therefore the social-economy context of prosperity theology has become a great attraction to impoverished people of Africa. Rather than the church ministers to be concerned about the land degradation, unemployment of vibrant and proactive youths, unrest and economic insecurity in African, they care more for their personal empowerment. One cannot understand fully a wrong inclination unless one knows the right inclination. Spurgeon repeated a very profound statement to his students, "if there is one central theme in all proclamation, it is the cross of our Lord Jesus Christ, the marrow of the Gospel". The Bible makes this fact abundantly clear.

\section{Prosperity Gospel/Theology}

\section{Origin and Growth of Prosperity Gospel:}


Prosperity gospel is sometimes referred to as the health and wealth gospel or the gospel of success [2]. It is a religious belief among some Christians that financial blessing is the will of God for them, and that faith, positive speech, and donations will increase one's material wealth. Though it is impossible to trace the prosperity gospel back to an exact starting point, there are at least three movements from which it draws its ideas. The 1st is the experience-centered Christianity, which was birthed in the mind of nineteenth-century theologian Friedrich Schleiermacher and has come to fruition in the form of the twentieth-century Charismatic movement. The 2nd philosophy that gave rise to the prosperity gospel was the "positive thinking" school of Norman Vincent Peale. Harvey Cox wrote concerning the prosperity gospel: "it owed much to the 'positive thinking' of the late Norman Vincent Peale" [3]. The 3rd modern movement that has influenced the prosperity gospel is simply the "American dream," or materialism. Prosperity theology first came to prominence in the United States during the "Healing Revivals' of the 1950s. Though the origin of this theology has been linked to the New Thought movement that began in the 19th century, the prosperity preaching thereafter figured prominently in the Word of Faith movement and 1980s televangelism. It was adopted by influential leaders in the Charismatic Movement in the 1990s and 2000s and promoted by Christian Missionaries throughout the world, sometimes leading to the establishment of mega-churches. Prominent leaders in the development of prosperity theology include E. W. Kenyon, Oral Roberts, TD Jakes, A.A Allen, Robert Tilton, T. L. Osborn, Joel Osteen, Creflo Dollar, Kenneth Copeland, Reverend Ike and Kenneth Hagin. Many so-called Pentecostal Preachers that are sole leader of their churches in Nigeria belong to this group. Prosperity gospel put emphasis on the Book of Malachi, the doctrine views the Bible as a contract between God and humans: if humans have faith in God, he will deliver his promises of security and prosperity. Confessing these promises to be true is perceived as an act of faith, which God will honour. The doctrine emphasizes the importance of personal empowerment, proposing that it is God's will for his people to be happy. Jesus' atonement is interpreted to include the alleviation of sickness and poverty, which are viewed as curses to be broken by faith.

\section{The Three Basic Classifications of Prosperity Theology:}

Basilius M. Kasera in his Master of Theology's thesis at South African Theological Seminary [4] divided Prosperity Theology into three main groups based on their views. There are:

1) Fierce proponents: with the view that the will of God for all Christians is to flourish in all areas of life. According to this group, prosperity preaching means having a holistic approach to man's needs including his material wellbeing. A reference to this is deduced from David Oyedepo's book [5] that argues that "possessing your possession" is part of God's covenant and believers ought to prosper. Oyedepo claims that this covenant is sealed by the death of Christ, that all who believe in the message of the gospel will along with the salvation of their souls obtain all good things in this world including wealth, health and total success.

2) Fierce opponents: In this group is Hank Hanegraaff [6] who believes that prosperity theology poses one of the greatest contemporary threats to orthodox Christianity 
from within. Through it, cultic theology is being increasingly accepted as true Christianity. Robison [7] said that prosperity theology appeals to the western materialistic mindset.

3) The Middle View: This group acknowledges some of the positive things in prosperity theology and says it is a wake-up call to the evangelical churches especially on the issues of faith though they state their disagreement with prosperity theology but refuse to condemn it outright by being cautious in drawing conclusions. Prosperity Preaching is a gospel of Wealth (financial wellness and opulence).

\section{Biblical Interpretation of Prosperity Gospel:}

Author Ken Sarles wrote of the prosperity preachers that their:

Method of interpreting the biblical text is highly subjective and arbitrary. Bible verses are quoted in abundance without attention to grammatical indicators, semantic nuances, or literary and historical context. The result is a set of ideas and principles based on distortion of textual meaning [8].

Indeed, a survey of the volumes of literature produced by the prosperity preachers/ teachers yields numerous examples of such misinterpretations. Sarles picked the book of 3 John 2, to examine both the prosperity gospel and orthodox interpretations of the text. In this verse, the Apostle John wrote, "Beloved, I pray that you may prosper in all things and be in health, just as your soul prospers"-3 John 2 NKJV. Prosperity Preachers interpret this verse to mean, that God wants all believers to "prosper in all things." Furthermore, their interpretation of this verse makes clear their claim that material prosperity is inseparably linked to spiritual growth. Oral Roberts, regarded by many to be the father of the prosperity gospel movement, claimed at the beginning of his ministry, during a time of search for direction, that God miraculously led him to 3 John 2, which he understood as a revelation of the prosperity gospel [9]. Another faith teacher who built his ministry around this faulty interpretation of 3 John 2 is Kenneth Copeland. Author Kenneth Kantzer noted that "Copeland misinterprets this [verse] as a universal promise," [10] and writer Bruce Barron remarked that Copeland uses the words so often that they appear to be the key verse of his ministry". A careful study of 3 John 2, however, reveals that John's purpose in writing 3 John 2 was not to teach doctrine; it was simply to open his letter with a greeting. This is not to say that doctrine cannot be derived from a non-doctrinal passage, for all Scripture is profitable for doctrine, but it is to say that one must be sensitive to the original author's intent. Therefore, the claim that 3 John 2 teaches the doctrine of prosperity ought to be disregarded. This paper agrees that the focus of the original text is a prayer-wish (a form of greetings) and not that all believers must have material prosperity. The term translated "prosperity" is a form of the Greek word eujodovw. This word, which is used only four times in Scripture, does not mean to prosper in the sense of "gaining material possessions", but rather means "to grant a prosperous expedition and expeditious journey", or "to lead by a direct and easy way" [10]. The wording of modern translations such as the New International Version reflects this nuance of the word. Therefore it is evident that preachers who understand 3 John 2 to translate to prosperity theology are misinter- 
preting the text. Five of the reasons, the prosperity gospel concerning wealth are inappropriate are:

1. It is built upon a faulty understanding of the Abrahamic covenant;

2. It is built upon a faulty understanding of the Atonement;

3. It is based upon a faulty understanding of the biblical teachings on giving;

4. It is based upon a faulty understanding of the biblical teachings on faith; and

5. In general the prosperity gospel has been constructed upon faulty biblicalinter pretation.

As scholar James R. Goff noted, God is "reduced to a kind of "cosmic bellhop" attending to the needs and desires of his creation" [12].

\section{The Theology of Prosperity Gospel/Preaching:}

"Theology is important", wrote scholar Millard J. Erickson, "because correct doctrinal beliefs are essential to the relationship between the believer and God" [13]. The emphasis of this paper is that the prosperity gospel is constructed upon a faulty theology. Consequently, many of its doctrines, including the preaching concerning wealth, are flawed. There are four crucial areas of error relating to the prosperity theology on wealth that are examined here. These areas are the "Abrahamic Covenant", the "Atonement", "Giving", and "Faith".

\section{Prosperity Theology and the Abrahamic Covenant}

The theological basis of the prosperity gospel is the Abrahamic covenant [14]. Edward Pousson stated the prosperity view on the application of the Abrahamic covenant when he wrote, "Christians are Abraham's spiritual children and heirs to the blessings of faith. This Abrahamic inheritance is unpacked primarily in terms of material entitlements". In other words, according to the prosperity gospel, the primary purpose of the Abrahamic covenant was for God to bless Abraham materially. Since believers are now "Abraham's spiritual children", they consequently have inherited these financial blessings of the covenant. Kenneth Copeland wrote, "Since God's Covenant has been established and prosperity is a provision of this covenant, you need to realize that prosperity belongs to you now!" [15] Referring to the prosperity theology of Kenneth Hagin, author Harvey Cox wrote, "Through the crucifixion of Christ, Christians have inherited all the promises made to Abraham, and these include both spiritual and material well-being." To support this claim, prosperity preachers such as Copeland and Hagin appeal to Gal. 3:14a, "that the blessings of Abraham might come upon the Gentiles in Christ Jesus." In their appeal to Gal. 3:14, they ignore the second half of the verse, which reads, "That we might receive the promise of the Spirit through Faith Gal. 3:14b (NKJV)"; where Paul clearly reminded the Galatians of the spiritual blessing of salvation, not the material blessing of wealth. Also prosperity preachers claim that the conduit through which believers receive Abraham's blessings is faith. This completely ignores the orthodox understanding that the Abrahamic covenant was an uncondition-

al covenant. That is, the blessings of the Abrahamic covenant were not contingent upon one man's obedience. Therefore, even if the Abrahamic covenant did apply to Christians, all believers would already be experiencing the material blessings regardless of 
prosperity theology.

\section{Prosperity Theology and the Atonement}

Theologian Ken Sarles wrote, "The prosperity gospel claims that both physical healing and financial prosperity have been provided for in the Atonement." This seems to be an accurate observation in light of teacher Kenneth Copeland's comment that "the basic principle of the Christian life is to know that God put our sin, sickness, disease, sorrow, grief, and povertyon Jesus at Calvary". This misunderstanding of the Atonement stems from two errors: 1) Fundamental misconception of the life of Christ; 2) The misinterpretation of 2 Cor. 8:9. Without exception, this is the verse to which prosperity preachers appeal to in order to support their view of the Atonement:

For you know the grace of our Lord Jesus Christ, that though He was rich, yet for your sakes He became poor, that you through His poverty might become rich-2

Cor. 8:9 NKJV.

The prosperity preachers misinterpreted this verse to mean that Paul was teaching that Christ died on the cross for the purpose of increasing believers' material net worth. Contextually, it is clear that Paul was teaching the Corinthians that since Christ accomplished so much for them through the Atonement, then how much more ought they empty themselves of their riches in service of the Savior. The verses later confirmed the real meaning, when Paul urged the Corinthians to give their wealth away to their needy brothers "that now at this time your abundance may supply their lack." -2 Cor. 8:14 NKJV. Philip E. Hughes in his commentary of 2 Cor. 8:9 says, "The logic implicit in the statement of this great truth is too obvious for anyone to miss it" [16].

\section{Prosperity Theology and Giving}

One of the most striking characteristics of the prosperity theologians is their seeming fixation with the act of giving. Followers of the prosperity preachers are urged to give generously and are told that, "True prosperity is the ability to use God's power to meet the needs of mankind in any realm of life" [17], and, "we have been called to finance the gospel to the world." While these statements appear to be true at face value, a closer examination of the theology behind them reveals that the prosperity gospel's emphasis on giving is not built on philanthropic or godly motives. The driving force behind this emphasis on giving is what Robert Tilton referred to as the "Law of Compensation." According to this law, which is supposedly based on Mark 10:30, Christians need to give generously to others because when they do, God gives back more in return. As Gloria Copeland puts it, "Give $\$ 10$ and receive $\$ 1000$; give $\$ 1000$ and receive $\$ 100,000$; in short, Mark 10:30 is a very good deal.” It is evident, then, that the prosperity gospel's doctrine of giving is built upon faulty motives. Whereas Jesus taught His disciples to "give, hoping for nothing in return,"-Luke 10:35 (NKJV) prosperity theologians teach their disciples to give because they will prosper more.

\section{Prosperity Theology and Faith}

Orthodox Christianity understands faith to be total surrender, believe and trust in Jesus Christ, the truth of His teaching, and the redemptive work He accomplished at Calvary, but prosperity preachers promote a different doctrine. In his book, The Laws 
of Prosperity, Kenneth Copeland wrote:

Faith is a spiritual force, a spiritual energy, a spiritual power. It is this force of faith, which makes the laws of the spirit world function. There are certain laws governing prosperity revealed in God's Word. Faith causes them to function.

This is not only faulty but also heretical understanding of "Faith". Later in the same book Copeland wrote:

If you make up your mind ... that you are willing to live in divine prosperity and abundance, ... divine prosperity will come to pass in your life. You have exercised your faith.

According to prosperity theology, faith is not a theocentric act of the will, or simply trust in God; rather it is an anthropocentric spiritual force, directed at God. Indeed, any theology that views faith solely as a means to material gains rather than the acceptance of heavenly justification must be judged faulty.

\section{Religious Impact of Prosperity Preaching on Sustainable Economic Development of African Nations}

\section{Religious Impact:}

There are many reasons the prosperity gospel is damaging the continent of Africa today but this paper examines five of those reasons because the reasons have variants depending on the African country involved. The five basic reasons discussed here are common to all African countries and they are the major reasons.

1. It is mixed with occultism birthing cultic theology: Before Christianity came to Africa especially Nigeria, people visited witch doctors and sacrificed goats or cows to get prosperity. They poured libations on the ground so the gods would hear their prayers. Today similar practices continue because the prosperity preachers have replaced the IFA priests. There are stories of church ministers who buried live animals under the floor of their churches to win people's favour. The people who follow these prosperity preachers are reminded that their promised windfall won't materialize unless they give large donations of money or properties.

2. It drives greed by fueling self-indulgence: The prosperity preacher teaches people to focus on getting, not giving. Church members are continually urged to sow financial seeds to reap bigger rewards. In Africa, Christian revivals are dedicated to collecting offerings in order to achieve wealth. Preachers tell their followers that spirituality is measured by their physical prosperity. This greed preached from the pulpit spreads like plague in God's house.

3. It promotes conceit: The greedy atmosphere in prosperity churches has produced arrogance and a warped style of leadership. A Kenyan, Gideon Thuranira, editor of Christian Professional magazine, called these men "church preneurs." They plant churches not because they have a burden to reach lost souls but because they see different currencies of the world when they fill an auditorium with chairs. The most suc- 
cessful prosperity preacher is the most dangerous because he can convince a crowd that Jesus died to give you a Lexus, airplane or several mansions. In Nigeria, there are many cases of theses preachers accumulating fabulous wealth and live in opulence as their followers become poorer.

4. It works against the formation of Christian character: The prosperity gospel is a poor imitation of the true gospel because it leaves no room for brokenness, suffering, humility or delay. Prosperity preachers promise instant results and overnight success; if you don't get your breakthrough, it is because you are not giving enough offering. Jesus calls us to deny ourselves and follow Him; prosperity preaching calls us to deny Jesus and follow our materialistic lusts. Some church ministers are so set on getting rich; they cannot go through the process of discipleship that requires self-denial. Spiritual formation has been jettisoned for materials' formation.

5. It keeps people in poverty: The government of Malawi was once under international scrutiny because of fraud carried out by top leaders. The so-called "Cashgate" scandal is that professing Christians in the administration of President Joyce Banda were implicated. One of these people stole millions of kwacha from the government and hid the cash in a teddy bear! Most people today in Malawi live on less than $\$ 1$ a day, yet their leaders have been known to buy fleets of cars and huge plots of land with money that was not theirs. Sadly, the prosperity gospel preached in Malawi has encouraged pastors and leaders to follow the same corrupt pattern. As a result, God's people have been financially exploited. The same thing happened in Nigeria during the administration of Goodluck Jonathan when the president of Christian Association of Nigeria was implicated in the seized cash from his plane by South African government. Jesus described false prophets as wolves in sheep's clothing. Churches have been growing rapidly in many parts of Africa today, yet sub-Saharan Africa is the only region in the world where poverty has increased in the past 25 years. So according to the statistics, the prosperity gospel is not bringing prosperity! It makes their followers poorer so it is a flawed message!

\section{The Bankruptcy of the Prosperity Gospel:}

Over one hundred years ago, the renowned pastor, Charles H. Spurgeon said to the then-largest congregation in all Christendom:

I believe that it is anti-Christian and unholy for any Christian to live with the object of accumulating wealth. You will say, "Are we not to strive all we can to get all the money we can?" You may do so. I cannot doubt but what, in so doing, you may do service to the cause of God. But what I said was that to live with the object of accumulating wealth is anti-Christian [18].

This gospel has been ascribed many names, such as the "name it and claim it gospel", the "blab it and grab it gospel", the "health and wealth gospel", the "word of faith movement", the "gospel of success," the "prosperity gospel," and "positive confession theology." In the words of Robert Tilton, one of the prosperity gospel's most wellknown spokesmen:

I believe that it is the will of God for all to prosper because I see it in the Word [of 
God], not because it has worked mightily for someone else. I do not put my eyes on men, but on God who gives me the power to get wealth [19].

Preachers of the prosperity gospel encourage their followers to demand of God everything from modes of transportation to homes, furniture, and large bank accounts.

Prosperity gospel is bankrupt because it deviates from the "True gospel" and proclaim "false gospels", which usually focus on the same basic fallacies by not matching up with Scripture. Any "gospel" which is inconsistent with or different from the clear teachings of the Bible is bankrupt-Gal. 1:6-10; 2 Cor. 11:3-4. Some specific brands of false gospels include:

- Salvation by works: The Bible says righteousness cannot be gained by doing good deeds against bad ones to see which prevail. Eph. 2:8-9; Ro. 4:1-3;

- Salvation is by personal righteousness: The Bible says no one is really righteous in comparison to God. Matt. 5:20; Rom. 3:10-11; Is. 64:6;

- Salvation is by keeping the law or a moral code: Phil. 3:4-9; Gal. 3:1-5; James 2:8-11; Rom. 7:7-12. The Bible says apart from God it is impossible to perfectly keep the Law. The Law was not designed to save for it was given to the redeemed people to show them how to live;

- Salvation is by family or ethnic heritage or tradition: The Bible says that is never the basis for salvation. Everyone must personally believe to be saved. John 8:31-47; Gal. 3:26-29;

- Salvation is by religious ritual: The Bible says religion and ritual do not save; only a right relationship to God does. Rom. 3:28-29; John 4:19-24;

- Salvation is by human reformation: The Bible says a new spiritual birth is required, not a superficial, shallow reform of lifestyle. John 1:12; 3:1-9; 1 Pet. 1:22-23;

- Salvation is by superior knowledge: The Bible says man's wisdom and human knowledge will not save - Col. 2:1-8; 1 Cor. 2:4-16; 1 Tim. 6:20. Knowledge which saves is not just based on facts but is also experiential and personal (religious experiences);

- Any gospel, which denies the real incarnation of Christ as a man is false. Scripture teaches His real humanity. 1 John 4:1-2; Rom. 8:1-4; Heb. 2:14-17; Gal. 4:4;

- Any gospel, which denies Jesus' bodily resurrection, is false. The resurrection declares God's approval of Christ, the acceptance of His sacrifice for sins, and proves He has broken the power of sin. Rom. 1:4; Acts 23:6-8; 1 Cor. 15:12-17; Acts 24:20-21;

- Any gospel, which denies the "Virgin birth" is false Luke 1:29-38; Heb. 7:26-28. If Jesus had an earthly father he had a sin nature and was not qualified to be God's perfect sacrifice. Jesus had to be born of a woman and to be human, yet be without sin supernaturally by the Holy Spirit;

- Any gospel, which denies that Jesus is God, is false. John 10:23-33; 1 John 2:20-23, Col. 2:9; John 1:1; Jude 4;

- Any gospel, which denies the authority, truth and accuracy of the Bible, is false. The 
Scriptures bear witness to Jesus. If they are wrong, then you cannot believe what they say about Christ. The Bible asserts its truthfulness. John 5:39-40; John 10:35; John 17:17.

There are other kinds of gospels, which deny a fundamental truth, add to the Gospel or states what the Gospel does not promise. These form the hallmark of the bankruptcy of prosperity gospel:

1) Gospel, which promises perfect physical health in this life as a result of salvation Acts 8:9-25. The main subject of salvation is the sin problem, not curing physical ills. (Is. 53:4-6 \& Mt. 8:14-16). Jesus in his earthly ministry fulfilled this prophecy in Isaiah and in His death brought perfect spiritual health. Eph. 1:7; 1Pet. 2:24-25. Physical ills, death, etc., are related to the curse of sin and the human body and are not removed until the eternal state when we have glorified, resurrected spiritual bodies. Rev. 21:1-4;

2) Gospel, which guarantees wealth and prosperity. Jesus came to bring eternal spiritual blessing, not earthly temporary material blessings. Matt. 6:19-21, 33; Luke 12:13-21; Gal. 3:14;

3) Gospel, which promises that Christ will solve all human problems. Christ came to save us from sin, not deliver us from every problem and trial. Earthly problems and trials cause us to trust in God, equip us to minister to others, and enable growth to spiritual maturity. John 16:33; 2 Cor. 1:3-11; 4:6-18; James 1: 2-7;

4) Gospel, which teaches that sin, is only a social problem or ill. Sin is anything, which violates or is contrary to the character of God. Man is a sinner by nature. Sin causes a separation between God and man and brings death and destruction. If sin is not real, then the cross was unnecessary. Jer. 17:9; Mark 7:19-21; Eph. 2:1-3; Rom. 5:18-19; 6:23; Is. 59:1-9; Gal. 2:17-21;

5) Gospel, which promises liberation from political, military, social, or economic oppression. Jesus came to set men free from slavery to sin, not earthly oppression. Not once in Christ's ministry did he advocate revolution or rebellion from earthly oppression; that would come in Christ's Millennial Kingdom reign on earth. John 18:33-37; Rev. 1:5-6; Is. 2:1-4; 11:1-9;

6) Gospel, which teaches universal salvation for all. Salvation is available to all, but not all are willing to come to Jesus and choose to receive it. Many choose to reject Christ. Matt. 7:13-14; Luke 23:39-43; 2 Pet. 2:1; Titus 1:13-16;

7) Gospel, which requires for salvation anything other than faith alone. To add any requirement to salvation other than faith is to render the cross a vain wasted act and to exalt man's part in salvation. Gal. 2:16-21; Phil. 3:9;

8) Gospel, based on anything other than the love, mercy, and grace of God. To do so is to attribute an impure or ulterior motive to God as if He will be trying to gain something. 1 John 4:7-12; Eph. 2:4-8.

\section{Prosperity Gospel and the Spirit of Capitalism:}

Ihenacho [20] observes that the contemporary Nigerian church is submerged in the quest for material benefits, prevalent in the society. The capitalistic tendencies have re- 
placed spiritual growth and moral sanctity towards an eternal life. Nothing is sacred when it comes to this spirit of capitalism. The preachers of Prosperity Gospel declare sufferers from maladies cannot be treated in hospitals but only through their own spiritual intervention. They charge exorbitant fees even before attempting a cure. Elements such as oil, handkerchief, water etc. are sold at exorbitant cost to their followers for miracles. They prey on these people in search of miracles in their troubled lives. The Punch newspaper of 18th May 2011 published a headline story: “Africa's wealthiest Pastors in Nigeria spend \$225 million on Private Jets”. In the News was David Oyedepo of Winners Chapel, believed to be Africa's richest gospel preacher. Oyedepo owns a private collection of four expensive aircrafts and a private hanger to park them. The overseer of the Redeemed Christian Church of God, Pastor Enoch Adeboye is another owner of a $\$ 30$ million Gulfstream jet among others. Pastor S. Adeyemi the founder of Daystar Christian Centre and a preacher of financial prosperity gospel also owns a jet. The spirit of capitalism has also seized the people who hear the prosperity gospel sermons. As A Yang points out: "nobody wants to attend a church service where the pastor dresses in simple clothes, rides a bicycle, and lives in a low-income house". The people will not believe such a pastor can perform miracles.

\section{Consequences of Prosperity Message for Public Morality:}

The nobility and integrity of the Christian faith is threatened by the preaching of prosperity gospel. The zeal to gain wealth by all means has adverse effect on the Africa nations. That is the reason crimes like armed robbery, kidnapping, ritualism, and fraudulent activities have increased. Some of these false preachers use socio-psychological manipulations to control and exploit their victims. They use techniques like altered states of consciousness, peer pressure, expectations, and hypnotic suggestions to prey on their victims. They falsely claim anointing from God by selling items like handkerchiefs, water, oil, candles of different colours and so on. The implications of prosperity preaching on African nations include loss of Godly character, loss of faith, lack of personal economic security and general well being of the people.

\section{Conclusions}

The written Word convicts people, but the preached Word converts people. The preaching of the Gospel brings people to faith in Jesus Christ, and accomplishes great things for God. It is then imperative that Ministers of God should know the Gospel fully, lest they fail in their calling to be proclaimers of the "Good News". Some of the preaching taking place in the name of evangelism misses the desired mark, at least to an extent. The cross of Jesus Christ is the marrow of the gospel. What prosperity gospel or theology does is rightly termed a "misnomer", or "missing the mark' and this paper condemns it.

The theological, biblical, and historical realities must be clearly understood and fully, not partially, declared in the presentation of the Gospel. It is clear that these basic truths centre in and on the person and work of Jesus Christ. Therefore, it must be stressed that messages must contain the essential kerygma that is the Gospel, if we are 
to expect God's full blessing upon our proclamation.

Many sermons today based on prosperity gospel seem bereft of any real content of the full kerygma. The preaching appeals to the imagination, the emotions, or the "Needs" of the moment and these are not what the New Testament means by preaching. "We preach Christ" (1 Cor. 1:23) must be the theme in all attempts to win people to Christ. This is the "meat" of the message.

\section{References}

[1] Foster, R.J. (1985) Money, Sex \& Power: The Spiritual Disciplines of Poverty, Chastity and Obedience. Hodder \& Stoughton, Toronto, 5.

[2] Kent, G. (2008) Behind the Prosperity Gospel. U.S. News \& World Report, Pejorative Nicknames Have Been Attached to the Theology, Including "Name It and Claim It" and "Blab It and Grab It".

[3] Cox, H. (1995) Fire from Heaven. Addison-Wesley, Reading MA, 271-272.

[4] Kasera, B.M. (2012) The Biblical and Theological Examination of Prosperity Theology and Its Impact among the Poor in Namibia. Thesis Submitted for the Degree of Master of Theology, South African Theological Seminary, 6-9.

[5] Oyedepo, D. (2007) Possessing Your Possession. Dominion Publishing House, Lagos, 63-65.

[6] Hanegraaf, H.(1993) What's Wrong with the Faith Movement (Part One): E. W. Kenyon and the Twelve Apostles of Another Gospel. Christian Research Journal, 15, 1-8.

[7] Robison, J. (2003) Another View of the Prosperity Gospel. Charisma (Electronic Journal), Accessed on 17 January 2011.

[8] Sarles, K.L. (1986) A Theological Evaluation of the Prosperity Gospel. Bibliotheca Sacra $143,337,338-339$.

[9] Barron, B. (1987) The Health and Wealth Gospel. Inter Varsity Press, Downers Grove, IL, $62,91$.

[10] Kantzer, K.S. (1985) The Cut-Rate Grace of a Health and Wealth Gospel. Christianity Today, 29, 14.

[11] Thayer, J.H. (1981) The New Thayer's Greek-English Lexicon of the New Testament. Hendrickson, Peabody, MA.

[12] Goff, J.R.Jr. (1990) The Faith That Claims. Christianity Today, 34, 21.

[13] Erickson, M.J. (1985) Christian Theology. Baker Book House, Grand Rapids, MI, 28.

[14] Copeland, G. (1973) God's Will Is Prosperity. Kenneth Copeland Publications, Fort Worth, TX, 4-6, 45, 54.

[15] Copeland, K. (1974) The Laws of Prosperity. Kenneth Copeland Publications, Fort Worth, TX, 41, 51 .

[16] Hughes, P.E. (1962) The Second Epistle to the Corinthians. New International Commentary on the New Testament, Eerdmans Publishers, Grand Rapids, MI, 300.

[17] Copeland, K. (1974) The Troublemaker. Kenneth Copeland Publications, n.d., Fort Worth, TX, 6, 26.

[18] Carted, T. (1988) 2200 Quotations from the Writings of Charles H. Spurgeon. Baker Book House, Grand Rapids, 216.

[19] Tilton, R. (1983) God's Word about Prosperity. Word of Faith Publications, Dallas, TX, 6. 
[20] Ihenacho, N. (2009) A Critical Look at Contemporary Nigerian Christianity Society for Research and Academic Excellence.

http://www.academicexcellencesociety.com/a_critical_look_at_contemporary_nigerian_chr istianity.pdf

Submit or recommend next manuscript to OALib Journal and we will provide best service for you:

- Publication frequency: Monthly

- 9 subject areas of science, technology and medicine

- Fair and rigorous peer-review system

- Fast publication process

- Article promotion in various social networking sites (LinkedIn, Facebook, Twitter, etc.)

- Maximum dissemination of your research work

Submit Your Paper Online: Click Here to Submit

Or Contact service@oalib.com 